\title{
Improve Performance of Black Cotton Soil using Different Materials for Pavement
}

\author{
Madhav Ratnadhariya ${ }^{1}$, Prof. Srinath Karli ${ }^{2}$, Prof. Smit Bhatt ${ }^{3}$ \\ Transportation Engineering ${ }^{1,2,3}$, Hasmukh Goswami College of Engineering, Vahelal, Ahmedabad, India ${ }^{1,2,3}$ \\ Email: ratnadhariyamadhav@gmail.com ${ }^{1}$
}

\begin{abstract}
Due to rapid growth of urbanization and industrialization, minimization of industrial waste is serious problem in present days. To encounter this innovative and nontraditional research on waste utilization is gaining importance now days. Soil improvement using the waste material like Slag, Rice husk ash, Silica fume etc, in geotechnical engineering has been recommended from environmental point of view.
\end{abstract}

Index Terms- Fly Ash, Rise Husk Ash, Silica Fume, Soil improvement.

\section{INTRODUCTION}

Black Cotton soil represent a well known category of problematic from civil engineering point of view. They exhibit large volumetric changes shrinkage and swelling behavior if the moisture content changed.

Due to this nature this type of soil is susceptible to damage to the structures and pavements founded on it.

In India structure founded in areas with soft or weak soil have need for improvement of soil properties by using additives.

Soil stabilization techniques are used to improve reducing expansive characteristics.

Coal fly ash are lightweight particles captured in exhaust gas by electrostatic precipitators and bag houses of coal fired power plants.

Silica fume also referred as micro-silica is a product resulting reduction of high purity quartz with coal in an electric arc furnace in the manufacture of silicon or Ferro -silicon alloy. Silica fume rises as an oxidized vapor. It is fine grey colored powder sometime similar to Portland cement or some flashes .Condensed silica fume is essentially silicon-dioxide (more than 90\%) in noncrystalline form.

The rice husk is the outmost layer of the paddy grain that is separated from the rice grains during the milling process.

Around $20 \%$ of paddy weight is husk and rice production Asia produce about 770 million tons of husk annually.

\section{LITRATURE REVIEW}

Many researchers are looking for alternative materials for soil stabilization, fly ash is an effective agent for chemical and mechanical stabilization of soil.

2.1 Saranjeet Rajesh Soni concluded that solid waste disposal is an economical and effective way to achieve improvement in engineering performance of black cotton soils. The stability of soil using fly ash and rice husk powder can be increased .

2.2 Abd.El-Aziz examined the effect of lime-silica fume stabilizers on engineering properties of clayey subgrades. They summarized that the plasticity index and swell potential decreases and CBR value increases significantly. There is improvement in shear strength parameter also.
2.3 Al-Azzawi studied effect of silica fume addition on behavior of silty clayey soils, they investigated that there is significant important on swelling pressure and compressive strength of composite samples with silica fume. The permeability of soil increased with increase in silica fume content. It is observed that the addition of silica fume decreases the development of cracks on the surface of compacted clay samples reducing the cracks width by $75 \%$.

2.4 Venu Gopal N. studied the soil properties with silica fume as stabilizer and comparing the same with other materials. The laboratory investigations indicate that soil samples possessing low strength can be treated with varying silica fume of $5 \%$ to $20 \%$ by weight of dry soil. The treated soil samples showed significant improvement in the strength characteristics.

2.5 Biswas studied the utilization of rice husk with lime in sub grade soil for a rural road; they concluded that a very little amount of lime (3\%) added to the clayey soil with RHA, improve the CBR value and compaction characteristics to a great extent.

2.6 M Karimi studied effect of lime and micro silica admixtures on silty sand soils, in presence of sulphates. Results showed that the addition of micro silica to the silty sand soil increases the CBR strength and decreases swelling, therefore micro silica waste material can be successively used to enhance the strength of silty soil.

\section{OBJECTIVES}

The main objective of this study is to evaluate the feasibility of using Rice Husk, Fly Ash and Silica fume as soil stabilization material. In this paper the effect of Rice Husk, Fly Ash and Silica fume on engineering characteristics of expansive clay like Black Cotton Soil has been presented.

\section{MATERIALS AND METHODOLOGY}

The black cotton soil has been used as a base material in this study It has been replaced partially by fly ash by weight of dry soil.

The soil is classified as clay of high plasticity with expansive behavior. Materials are mixed on percentage basis i.e. $0 \%, 10 \%$, and $20 \%$ by weight of dry soil respectively. The following Tests were 


\section{Available online at www.ijrat.org}

conducted on black cotton soil and mixes; as per relevant IS Code.

[1] Classification of soil

[2] Liquid Limit test

[3] Plastic Limit test

[4] Plasticity Index

[5] Grain size distribution

[6] Compaction Test

[7] Unconfined Compressive Strength

[8] California Bearing Ratio Test

\section{WORK CARRIED OUT}

Table 1. Engineering Properties of Black Cotton Soil.

\begin{tabular}{|l|l|l|}
\hline $\begin{array}{l}\text { Sr. } \\
\text { No. }\end{array}$ & Particulars & $\begin{array}{l}\text { Test } \\
\text { Results }\end{array}$ \\
\hline 1 & Classification of soil & CI \\
\hline 2 & Liquid Limit test(\%) & 48 \\
\hline 3 & Plastic Limit test(\%) & 20 \\
\hline 4 & Plasticity Index(\%) & 28 \\
\hline 5 & $\begin{array}{l}\text { Grain size distributation } \\
\text { Sand(\%) } \\
\text { Clay(\%) }\end{array}$ & 6 \\
\hline 6 & $\begin{array}{l}\text { Compaction Test } \\
\text { OMC(\%) } \\
\text { MDD(kN/m^3) }\end{array}$ & 12.5 \\
\hline 7 & $\begin{array}{l}\text { Unconfined Compressive } \\
\text { Strengths }\end{array}$ & qu=12 \\
\hline 8 & California Bearing Ratio & 3.310 \\
\hline Table 2 Enging
\end{tabular}

Table 2. Engineering Properties of Rice Husk.

\begin{tabular}{|c|c|c|c|}
\hline $\begin{array}{l}\text { Sr. } \\
\text { No }\end{array}$ & Particulars & $\begin{array}{l}\text { Test } \\
\text { Result } \\
\mathrm{s} \\
(5 \%)\end{array}$ & $\begin{array}{l}\text { Test } \\
\text { Result } \\
\text { s } \\
(10 \%)\end{array}$ \\
\hline 1 & Liquid Limit test(\%) & 48 & 50 \\
\hline 2 & Plastic Limit test(\%) & 22.22 & 23 \\
\hline $\begin{array}{l}\text { Sr. } \\
\text { No }\end{array}$ & Particulars & $\begin{array}{l}\text { Test } \\
\text { Result } \\
\mathrm{s} \\
(5 \%)\end{array}$ & $\begin{array}{l}\text { Test } \\
\text { Result } \\
\text { s } \\
(10 \%)\end{array}$ \\
\hline 3 & Plasticity Index(\%) & 25.78 & 27 \\
\hline 4 & $\begin{array}{l}\text { Compaction Test } \\
\mathrm{OMC}(\%) \\
\operatorname{MDD}\left(\mathrm{kN} / \mathrm{m}^{\wedge} 3\right)\end{array}$ & $\begin{array}{l}13 \\
1.594\end{array}$ & $\begin{array}{l}11 \\
1.627\end{array}$ \\
\hline 5 & $\begin{array}{l}\text { Unconfined } \\
\text { Compressive } \\
\text { Strengths }\end{array}$ & 11.9 & 14.2 \\
\hline 6 & California Bearing & 2.961 & 3.019 \\
\hline
\end{tabular}

Ratio

Table 3. Engineering Properties of Fly Ash.

\begin{tabular}{|l|l|l|l|}
\hline $\begin{array}{l}\text { Sr. } \\
\text { No. }\end{array}$ & Particulars & $\begin{array}{l}\text { Test } \\
\text { Results } \\
(5 \%)\end{array}$ & $\begin{array}{l}\text { Test } \\
\text { Results } \\
(10 \%)\end{array}$ \\
\hline 1 & Liquid Limit test(\%) & 52 & 55 \\
\hline 2 & Plastic Limit test(\%) & 23.07 & 34.92 \\
\hline 3 & Plasticity Index(\%) & 28.93 & 20.08 \\
\hline 4 & $\begin{array}{l}\text { Compaction Test } \\
\text { OMC(\%) } \\
\text { MDD(kN/m^3) }\end{array}$ & 13 & 11 \\
\hline 5 & $\begin{array}{l}\text { Unconfined } \\
\text { Compressive Strengths }\end{array}$ & 13.6 & 11.8 \\
\hline 6 & $\begin{array}{l}\text { California Bearing } \\
\text { Ratio }\end{array}$ & 3.496 & 3.629 \\
\hline
\end{tabular}

Table 4. Engineering Properties of Silica Fume.

\begin{tabular}{|l|l|l|l|}
\hline Sr. & Particulars & $\begin{array}{l}\text { Test } \\
\text { Results } \\
(5 \%)\end{array}$ & $\begin{array}{l}\text { Test } \\
\text { Results } \\
(10 \%)\end{array}$ \\
\hline 1 & Liquid Limit test(\%) & 50 & 53 \\
\hline 2 & Plastic Limit test(\%) & 27.27 & 33.33 \\
\hline 3 & Plasticity Index(\%) & 22.73 & 19.67 \\
\hline 4 & $\begin{array}{l}\text { Compaction Test } \\
\text { OMC(\%) } \\
\text { MDD(kN/m^3) }\end{array}$ & 10 & 8 \\
\hline 5 & $\begin{array}{l}\text { Unconfined } \\
\text { Compressive Strengths }\end{array}$ & 1.655 & 2.041 \\
\hline 6 & $\begin{array}{l}\text { California Bearing } \\
\text { Ratio }\end{array}$ & 4.413 & 5.110 \\
\hline & & & 17 \\
\hline
\end{tabular}

\section{CONCLUSION}

We can say that Liquid Limit and Plastic Limit of fly ash is more compare to Silica fume and rice husk.

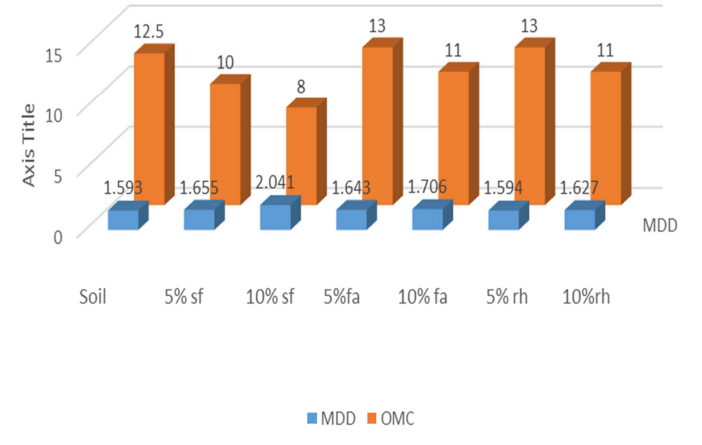




\section{International Journal of Research in Advent Technology, Vol.7, No.4, April 2019}

E-ISSN: 2321-9637

\section{Available online at www.ijrat.org}

We can say that MDD of silica fume is more compare to fly ash and rice husk.

$\mathrm{OMC}$ of silica fume is less compare to fly ash and rice husk.

We can say that value of shearing stress in silica fume is more compare to fly ash and rice husk.

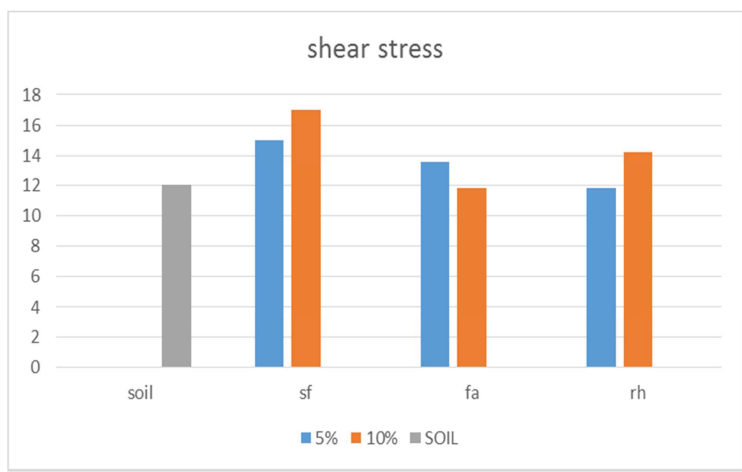

We can say that value of CBR in silica fume is more compare to fly ash and rice husk.

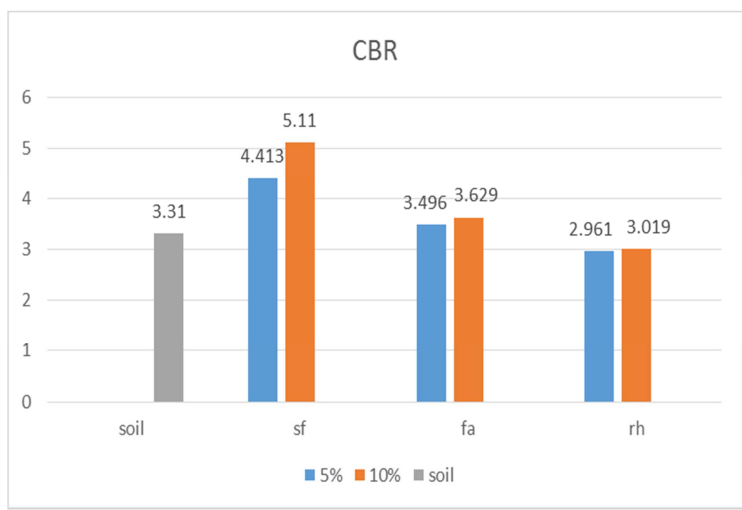

\section{FIGURES}

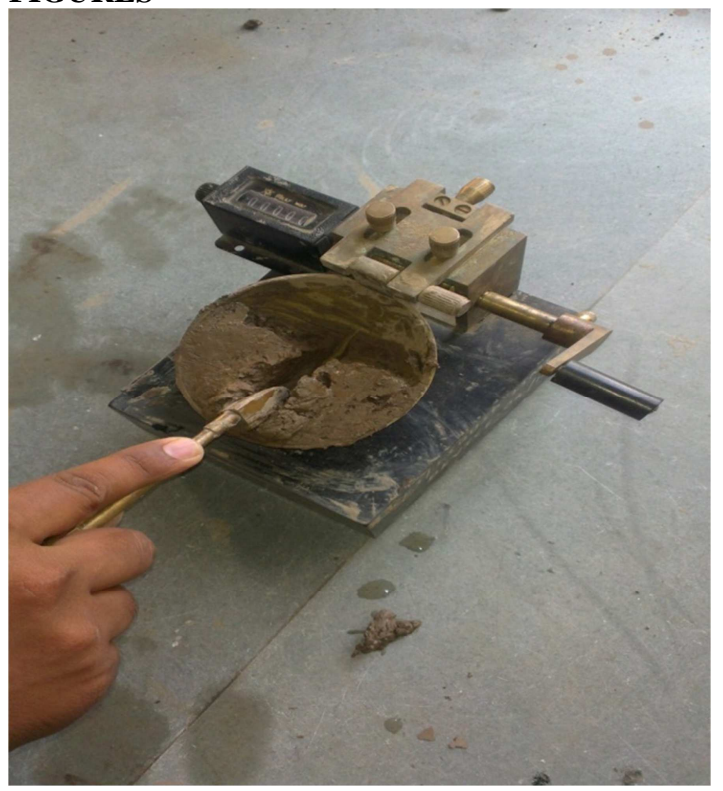

Fig 1. Liquid Limit Test
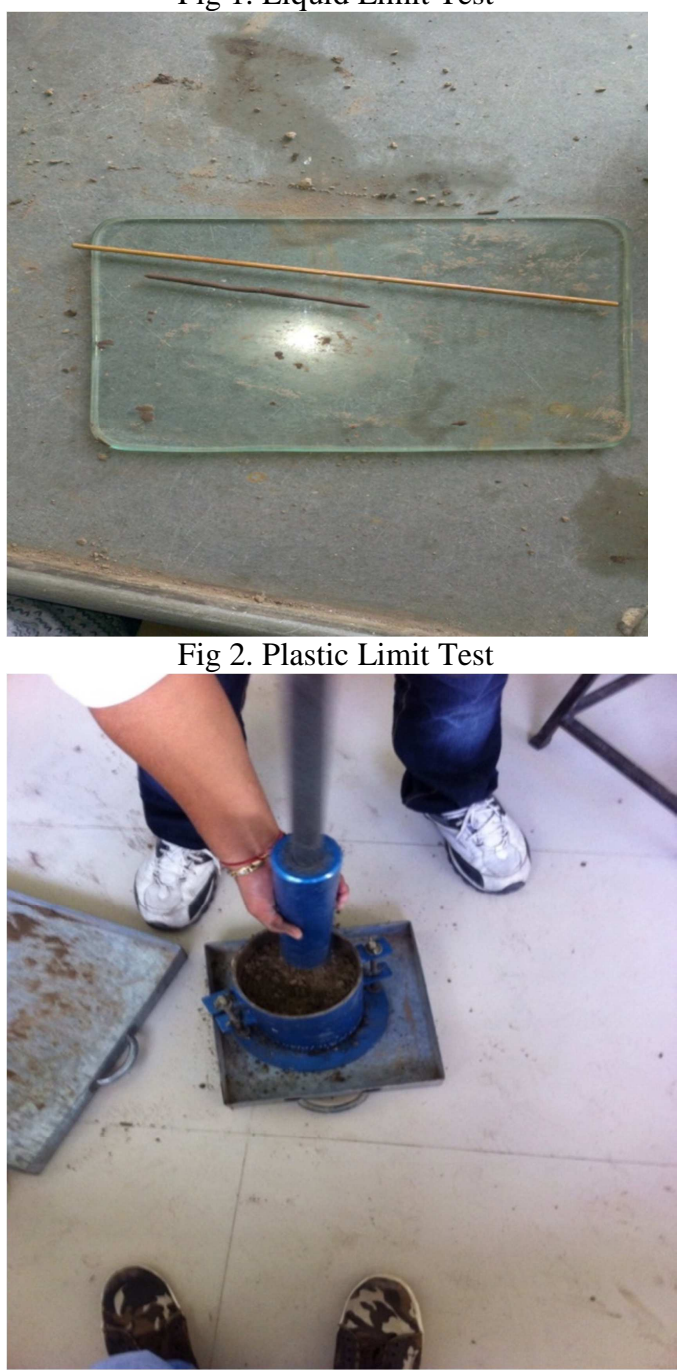

Fig 3. Procter Test

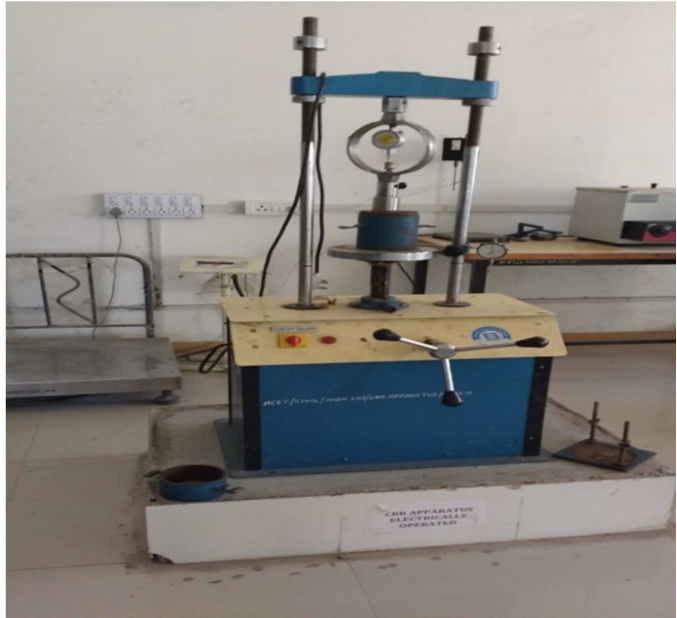

Fig 4. CBR Test

\section{ACKNOWLEDGMENTS}

I'm Heartily Thankful to Prof. Srinath Karli \& Prof. Smit Bhatt for giving tips, every possible help, 


\section{Available online at www.ijrat.org}

moral support, suggestions, and constant guidance during the entire span of my post- graduation study. I'm Grateful to have Prof. Srinath Karli as my Guide for the post-graduation study.

\section{REFERENCES}

[1] Saranjeet Rajesh Soni "Disposal of solid waste for black cotton soil stabilization", International Journal of Advanced Engineering Sciences and Technologies Vol No.8, Issue No. 1,113-120 (Soni).

[2] Abd.El-Aziz (2004) "The effect of Lime-Silica Fume Stabilizer on Engineering Properties of Clayey Subgrade", Fourth Mansoura International Engineering Conference ( $4^{\text {th }}$ IEC), Faculty Of Engineering, Mansoura University, Egypt (Abd.El-Aziz).

[3] Al-Azzawi (2012) "Effect of Silica Fume Addition on the Behavior of Silty-Clayey Soils", Journal of Engineering and Development Vol. 16, No 1 (Al-Azzawi).

[4] Venu Gopal.N "Study of Soil Properties with Silica Fume as Stabilizer and Comparing the same RBI -81 and Cost Estimation", PG diploma in Highway Engineering, Visvesvaraya Technological University, Belgium (N).

[5] Biswas (2012) "Utilization of Rice husk with Lime in Subgrade Soil for a Rural Road", International Conference on Emerging Frontier in Technology for Rural Area (Biswas).

[6] M Karimi (2011) "Stabilization of silly sand soils with lime and micro silica admixture in pressure of sulphates", Pan -Am CGS , Geotechnical Conference (Karimi). 